\title{
Developing Social Resilience and Building a Culture of Nationalism in the City of Batam, Indonesia
}

\author{
Sylvia P. Delima ${ }^{1}$, Paulus Wirutomo ${ }^{2}$, Setyo S. Moersidik ${ }^{3}, \&$ Abimanyu T. Alamsyah ${ }^{4}$ \\ ${ }^{1}$ School of Environmental Science, Universitas Indonesia, Jakarta, Indonesia \\ ${ }^{2}$ Department of Sociology, Faculty of Social and Political Sciences, Universitas Indonesia, Depok, Indonesia \\ ${ }^{3}$ Department of Civil Engineering, Faculty of Engineering, Universitas Indonesia, Depok, Indonesia \\ ${ }^{4}$ Department of Architecture, Faculty of Engineering, Universitas Indonesia, Depok, Indonesia \\ Correspondence: Sylvia P. Delima, School of Environmental Science, Universitas Indonesia, Jalan Salemba \\ Raya 4, Jakarta 10430, Indonesia. E-mail: prisca.d@gmail.com
}

\author{
Received: April 15, 2019 \\ Accepted: May 1, 2019 \\ Online Published: May 31, 2019 \\ doi:10.5539/ass.v15n6p19 \\ URL: https://doi.org/10.5539/ass.v15n6p19
}

\begin{abstract}
International ports serve and expedited interaction between nations. Building a modern international port city and advanced society dwellers within it heavily depends on socially sustainable development, and on the level of social resilience of its residents. The rapid development of an international port city cannot disregard many foreign interests in the City's decision making; therefore, the lack of a culture of nationalism is investigated. This paper tries to portray that building social resilience is hand-in-hand with building a culture of nationalism, and it exists in the international port city setting such as the City of Batam. A mixed method analysis is used to get determinants of social resilience and nationalism. It is used a systematic review of peer-reviewed academic journal articles published between 2013 and 2018 to scope and synthesize assessment criteria; then it is compared with the quality of socio-cultural life condition from the survey and in-depth interview. The analysis results show a correlation between economic and political powers and building the local identity and culture of nationalism. In the context of being local, being national, and being "other" in the regional area, this study also shows that building a culture of nationalism is related to socially sustainable development, and nationalism is not correlated with the place of living but to the efforts of citizen participation in sustainable development. Therefore, building social resilience is also building a culture of nationalism, and it makes an international port city distinctly unique despite its internationalism characteristic.
\end{abstract}

Keywords: culture of nationalism, Indonesian nationalism, international port city, local identity, national identity, social resilience development, sustainable development

\section{Introduction}

The City of Batam in Indonesia has been designed from its preliminary development in the 1970s to be a modern international port city (Badan Pengusahaan Batam, 2014). Many foreign investors who have the economic power in the city do not only give internationalism color to the city but also lead to the city's cultural transformation. This condition has also enriched the multicultural condition in the City of Batam in which there is no dominant ethnic group in the city or specific culture to be followed as generally happened in other cities in Indonesia. But, on top of that, the adopted internationalism condition often leads to an understatement of the lack of Indonesian culture.

The geographical location of the city in the vicinity of Singapore and Johor Bahru, Malaysia also gives another burden to this island city to show its specific identity of being part of Indonesia. Not only its border location, the condition of being the third busiest entrance gate into Indonesia, makes the interaction between nations is considered very high. Such interaction is believed directly affect the lifestyle adoption that either supplement in one hand or derogate the Indonesian culture on the other hand.

To show a strong Indonesia sovereignty in the city, ideally, a bright and distinctive Indonesian nationalism should also be displayed by the city dwellers, despite its geolocation in the border area as well as global-multiculturalism that unavoidably attached with the nature of an international port. The tagline of the City of Batam itself, i.e., "building a port city with advanced society in terms of thinking, spirituality, and material 
wealth" that locally referred as Bandar Madani deals with sustainable development and social resilience. Therefore, the question lays not only on the city society's identity in the local, national, and regional context in relation on the culture of nationalism but also on how the development has affected the social resilience condition and whether there is any relationship in building the culture of nationalism.

\section{Literature Review}

There are two concepts on socially sustainable development highlighted in this paper, i.e., social resilience and the culture of nationalism. The combination of both will lead to a higher level of social development. In this case, we based the terminology of sustainable social development as the situation perceived as social well-being and social opportunity that guaranteed by adequate public involvement fostering fast and participatory economic growth, usually in the provision of primary education, health care, social security, and other related fields (Dreze \& Sen, 1999).

We based our opinion on social resilience as to how the community attached to its social background and its effort to survive (Fröhlich \& Gioli, 2015). Basically, social resilience is a conceptual framework to understand the risks and facing changes and how the local community can adapt towards and bouncing back from disruptive events (Adger, 2000). Moreover, social resilience should be seen with evolutionary perspective as the ability of complex socio-ecological systems to change, adapt, and crucially transform in response to stresses and strains, yet it still maintains the system's ability to grow (Community and Regional Resilience Institute, 2013). In this research, social resilience refers to the building of the culture of nationalism based on the analysis utilizing the interconnected structural-processual-cultural elements that work as the foundation of the quality of socio-cultural life condition (Wirutomo, 2014 and 2016, as shown in Figure 1). The quality of socio-cultural life condition itself is the interaction of structural-processual-cultural elements that can be found in the society by analyzing the facts and the residents' opinion on the development result, as well as their perception on the culture of nationalism.

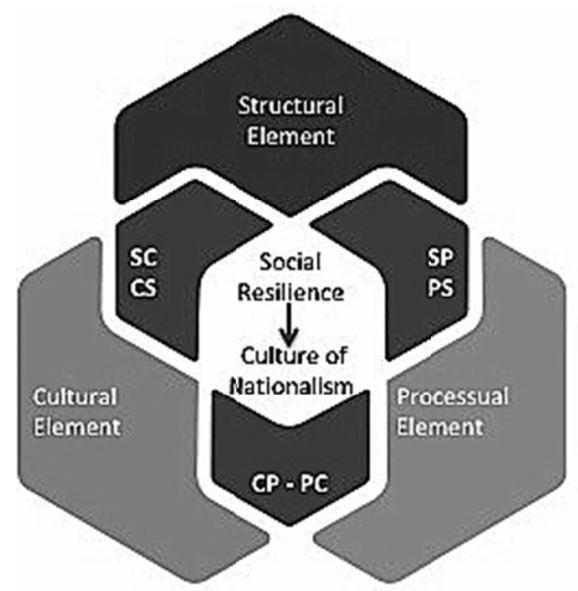

Figure 1. Social Resilience towards a Culture of Nationalism based on the Interaction of Structural-Processual-Cultural Elements

Renan mentioned that nationalism is usually being perceived as willingness to unity without coercion based on collective interest to create a national identity (in Jati, 2017). In addition to that, promoting community rights in a specific span of territories (Jati, 2017), or even detailing the image of a Nation State by creating a national identity of being part of a nation or having a social bond following Clifford Geertz's idea (Bošković, 2002) is also considered as a nationalism condition. The idea of a nation state is using the national bond as national interest and national identity to mobilize the nation (Bloom, 1990), or representation of ideas and values towards self-determination (Smith, 1991), as well as a part of global-multiculturalism (Kellas, 1998) driven by foreign policy decision making to ensure peace relationship between nation (Mylonas \& Kuo, 2018). In Indonesia, nationalism is usually perceived as one of the basic state principles that cannot be separated from Soekarno's ideas. As the Founding Father, Soekarno mentioned that the nation foundation should not be separated from science, willingness, and action of the people (Soekarno, 2006).

Specifically, Soekarno (2006) states that people, by the collective agreement, are understandable may able to create a nation. Moreover, nationalism was described as the collective will of the nation, or in Soekarno's terminology as "nationals geest - nationals wil-nationals daad". Based on his assumption, in order to activate 
the collective will of the nation, there should be a culture in where one should have the knowledge (of science) and the understanding and the acknowledgment that will create willingness to accept, and the most critical thing the willingness to act according to the shared knowledge, understanding and acknowledgment. Nationalism will then have a broader context of knowledge in which the leader of the nation should activate it into national action based on the generated collective will (Soekarno, 2006). Summing up, Indonesia's nationalism is a creation of collective knowledge from diverse communities in Indonesia in which multiculturalism in Indonesia is beyond ethnicity, religion, and race. Hence, it should not be chauvinism but a culture that should be able to activate social justice for all people that along with time will become a national will.

\section{Methods}

A mixed method analysis is used to get to know the condition of social resilience and the culture of nationalism and their relation to sustainable social development in the City of Batam. This research is using the synthesis techniques by analyzing systematic review gathered from literature data of peer-reviewed academic journal articles gathered from the e-resources of the Indonesian National Library. These literature databases are generated from the data within the time frame of 2013-2018, under the combination of search terms, i.e., nationalism, social resilience, and development. This literature generation is to scope and synthesize assessment criteria that will be compared and contrasted with the results from the survey conducted in the City of Batam.

The survey itself is a combined close and open-ended question. The Likert-scale questionnaire is used to determine the resident's perception of development results, while the open-ended questions allow getting an in-depth interview with the target residents of the City of Batam. The questions are based on the Planet sections of United Nations Sustainable Development Goals (United Nations, 2015) that intended to seek pieces of evidence explicitly on three categories: environment health and degradation, sustainable consumption and production, and supports for living and employment, as well as the supplementary maritime aspects to reflect the local geographic condition. In addition to that, to increase our knowledge on the society's perception on nationalism, we also add a section on the attachment of the City of Batam residents to the place where they are living in as well as the their opinion on being local, being national, as well as being "other" in the context of the regional condition.

The results of both set of data are then analyzed by using Wirutomo's structural-processual-cultural elements approach (Wirutomo, 2016) to determine the quality of socio-cultural life that might lead to sustainable social development that has impacts in building the culture of nationalism. The compare and contrast of these analyses will determine the condition of developing social resilience and building a culture of nationalism in the City of Batam, Indonesia.

\section{Results}

The synthesis from the English language peer-reviewed academic journal articles that have been gathered using search variances of social resilience, nationalism, and social development within the time frame of 2013-2018 listed 146 results by relevance. The results of essential terminologies emerged as best practices and lesson learned listed in Table 1.

Table 1. Best practices and lesson learned in social resilience, nationalism, and development aspects

\begin{tabular}{|c|c|}
\hline Aspects & Determinants with Major Best Practice and Lesson Learned Findings \\
\hline $\begin{array}{l}\text { Social } \\
\text { Resilience }\end{array}$ & $\begin{array}{l}\text { Social Resilience Adoption and Adaptation } \\
\text { - } \quad \text { Social supports (Guarnacci, 2016) } \\
\text { - } \quad \text { Social relationships, social complexity (Connon, 2017), social contracts (Tsai, 2018) } \\
\text { - } \quad \text { Social impact assessment (Hansen et al., 2016) } \\
\text { Social Transformation and Efforts for Transformation } \\
\text { - } \quad \text { Social innovations (Kluvánková et al., 2018) \& regeneration (Beel et al., 2017) } \\
\text { - } \quad \text { Social networks and local culture (Miller \& Pescaroli, 2018) and addressing the cultural and } \\
\text { institutional forces that work to reinforce inequality and marginalization (Shah, 2016) } \\
\text { - } \quad \text { Social roles (Drucza \& Peveri, 2018) } \\
\text { Capacities of knowledge transmission (Connon, 2017) and redistribution (Shah \& Lopes Cardozo, } \\
\text { 2014) including the connection to the global situation (Stenbacka \& Bygdell, 2018) }\end{array}$ \\
\hline Nationalism & $\begin{array}{l}\text { Security and justice } \\
\text { - State control that allows efficient and effective distribution (Tsai, 2018); transforms nature from a } \\
\text { constraining externality into an integral part of social analysis and transformation (Hoffmann, 2018); }\end{array}$ \\
\hline
\end{tabular}


where many stakeholders build knowledge and capabilities (Noboa \& Upham, 2018)

- $\quad$ Diversity acknowledgment (Shah \& Lopes Cardozo, 2014) and public engagement (Delina, 2018)

- $\quad$ Social safety and security (Høyland, 2018); cross-border cooperation (Castanho et al., 2018); and public participation (Ganbold \& Ali, 2017) in transnational settings (Heinderyckx, 2015)

Good environmental governance

- The socioecological system in which knowledge, practice, and beliefs coevolve: culture is a crucial factor in their generation and persistence (von Heland \& Folke, 2014) and involving indigeneity (Zimmerer, 2015)

- $\quad$ The sense of place (Dukpa et al., 2018)

Good urban conflict and crisis management (including media literacy)

- Knowledge transmission between diversifying social groups (Connon, 2017)

- Mitigation (Hirsch, 2015) and crisis alertness including Development Forced Displacement and Resettlement (Wilmsen \& Webber, 2015); and towards minorities such as children (Hoang et al., 2015)

\section{Democratic stability (leadership)}

- Key opinion leaders in the networks and identifies channels of resources/information (Guarnacci, 2016)

- $\quad$ Redistribution of educational opportunities and welfare access (Shah \& Lopes Cardozo, 2014)

Appropriate social development policies

- Understanding of Social Innovations (Kluvánková et al., 2018)

Social

Development

- Determination of the vital development trajectories (Kluvánková et al., 2018), understanding the city as a whole to understand resilience (Walters, 2015)

- Determine the adaptive or transformative character of Social Innovations (Kluvánková et al., 2018) and develop full potential social-spatial perspective (Bridge, 2018)

- Adoption a multi-systemic approach: local cultural practices, a capacity of local people to take control (Miller \& Pescaroli, 2018)

- $\quad$ Strategic social impact assessment (Hansen et al., 2016)

From the synthesis analysis, we get the determinants of building social resilience and the determinants of building a culture of nationalism that related to sustainable social development. The determinants of building social resilience consist of social transformation and efforts for transformation, as well as social resilience adoption and adaptation. On the other hand, there are five determinants of nationalism, i.e., security and justice, good environmental governance, good urban conflict management (including media literacy), and democratic stability, as well as appropriate social development policies.

Table 2. Pieces of evidence-based of the Planet sections of the United Nations' Sustainable Development Goals

\begin{tabular}{|c|c|}
\hline Sub-sections & Considered Important Determinants \\
\hline Environmental health and degradation & $\begin{array}{ll}\text { - } & \text { Clean water management } \\
\text { - } & \text { Sanitation management } \\
\text { - } & \text { Solid waste management } \\
\text { - } & \text { Liquid waste management, and } \\
\text { - } & \text { Environmental protection }\end{array}$ \\
\hline Sustainable consumption and production & $\begin{array}{ll}\text { - } & \text { Employment and Employment opportunities } \\
\text { - } & \text { Access to make a decent living } \\
\text { - } & \text { Access to social welfare } \\
\text { - } & \text { Support toward innovation } \\
\text { - } & \text { Maritime aspects for sustainable development }\end{array}$ \\
\hline Supports for living and employment & $\begin{array}{ll}\text { - } & \text { Investments } \\
\text { - } & \text { Job training and Skill training } \\
\text { - } & \text { Workforce policies } \\
\text { - } & \text { Development policies }\end{array}$ \\
\hline
\end{tabular}


The second set of data from 110 samples was generated from a survey in the City of Batam. We use the determinants on the Planet sections of United Nations' Sustainable Development Goals (SDGs) to get some pieces of evidence-based explicitly on three categories: environmental health and degradation; sustainable consumption and production; and supports for living and employment. These original SDGs' determinants are listed in Table 2, that we include specifically the maritime aspects of sustainable development to suit the local geographic condition.

During the survey, we asked the respondents to answer a Likert-scale questionnaire that gives the range of 1 (bad), 2 (not too bad), 3 (good), 4 (very good), to 5 (excellent). There is an average of $20 \%$ informants who give 1 or 2 scales and answer everything at least 3 (good) for each question. The most reliable result is on access to make a decent living category in sustainable consumption and production sub-sections where $35 \%$ of informants consider it as excellent. However, when we probe into the mentioned three categories, we get a more holistic idea on the residents' opinion on the place where they are living as well as their place in it.

In environmental health and degradation section, we tried to find out the informants opinion on the management of clean water, sanitation, wastes management, and environmental protection. The informants' satisfaction in this section is due to a series of local government policies that are adequately implemented. The status of the city as an international port give support to the implementation of sound environmental management since the city strives to its best to attract investment for its exclusive economic zone. However, the results show that a healthy environmental condition seems to be focused on the city center and the industrial zone. The main concern is in the suburban area that farther away from the city center, as well as the small islands surrounding the three big islands in the City of Batam that may not have the luxury of proper environmental management. The informants, even though state their satisfaction on necessities especially on the service of clean water, sanitation, waste management in the island, ask for better quality services. They are also very conscious of plastic and hazardous waste in the coastal area drifted by the sea-current or dumped in the international waters. The informants agree that it is challenging to control plastic or hazardous waste without adequately sufficient land and sea patrols and law enforcement.

For the sustainable consumption and production section, we tried to find out the informants' opinion on the employment condition and employment opportunities, the access to make a decent living, the access to social welfare, the support toward innovations, as well as the maritime aspects for sustainable development. Many informants were questioning maritime development. We often heard the complaints on there are no direct strategies to support maritime-related industries and development. Despite the economic downturn, the maritime-economic side still has some opportunities and make the City of Batam is considered better than other Indonesian cities in the western region. However, most of the informants also mentioned the need to support and develop the tourism industry, specifically for the Meeting, Incentive, Conference, and Exhibition purposes, water sports and coastal tourism. In addition to that, based on the demographic condition in which $74 \%$ of the residents of Batam are the young generation, the digital and internet-based business is another choice for consideration, especially since the City of Batam is the internet backbone of Indonesia. Ensuring the City of Batam's sustainable consumption and production is essential according to all informants, to keep the identity of the city as one of the most progressive cities in Indonesia. Therefore, continuous innovation is one way to keep the progress is going on as well as to increase social welfare and access to quality living.

In the supports for living and employment section, we tried to find out the informants opinion on the investments climate, job training and skill training, workforce policies, and development policies. The City of Batam still has the Free Trade Area section, where the foreign investors can get various benefits. However, the investment climate is declining, and the informants blame the current direct competition from Johor Bahru, besides questioning the unstable workforce policies. The shift of development from the industrial city to become ordinary metropolitan is one of the biggest concerns. However, the informants are mentioning that there is a more workforce skill on demand for tourism, hospitality, and digital business beside the conventional electronics as well as shipyard and shipbuilding industries. Some private enterprises in cooperation with the local community college have tried to offer skill training, but the informants considered that it is not enough.

For additional information on the attachment of the City of Batam residents to the place where they are living, we asked on whether they are still willing to stay in the City of Batam and their opinion on this matter. The data shows that more than halves of the residents of the City of Batam are coming from other areas in Indonesia. The results show that despite the current decreasing economic condition, $72 \%$ percent of the informants are willing to stay since they have considered Batam as their hometown. Consequently, they are willing to take care of the City, both physical and social environment. Most informants consider themselves as "Batam people," and it is distinctively different from other nearby cities due to its multiculturalism and they are very proud with the 
identity as the international port city as well as the rapid modern development of the City. However, they do question the central government policy on national food resilience that limits the availability of fresh food grown or gathered locally. In their opinion, such a policy limits the people resilience and chance to get a quality of living. By the quality of living, the informants refer it to the level of quality of living in Singapore as the benchmark. Other countries in Asia are considered not essential or have the level of quality of living standard below Singapore's.

The analysis findings (shown in Table 3) show that $80 \%$ of respondents mentioned that sustainable consumption and production is considered as the most important, then it is followed by environmental health and degradation (58\%) and supports for living and employment (76.25\%). It also shows that access to better living and social welfares, and innovations, will lead to sustainable consumption and production.

Table 3. Determinants on Building Sustainable Development from the Qualitative Data

\begin{tabular}{cl}
\hline Aspect & \multicolumn{1}{c}{ Determinants } \\
\hline & - $\begin{array}{l}\text { Sustainable consumption and production is considered more important than environmental } \\
\text { health and environmental degradation or supports for living and employment } \\
\text { Access to a better living and social welfares, and innovations will lead to sustainable } \\
\text { consumption and production }\end{array}$ \\
$\begin{array}{c}\text { Sustainable Development } \\
\text { based on the Place }\end{array}$ & - $\begin{array}{l}\text { The communities are open to change and transformation that may lead to access to a better } \\
\text { living and social welfares, and welcome innovations related to both physical and social } \\
\text { development, and } \\
\text { Nationalism is not correlated with the place of living but to the efforts of citizen } \\
\text { participation in the development. }\end{array}$ \\
\hline
\end{tabular}

In addition to that, the survey shows that the residents are open to change and transformation that may point towards access to better living and social welfares, and welcome innovations related to both physical and social development. From the qualitative data, the informants also stressed out that nationalism is more on the joint-effort and participation in the development through many ways, including working hard, paying taxes, and keep the good relationship with the citizens of other countries.

\section{Discussion}

In the City of Batam beside the applicable rules and regulations, the restrictive limited physical environment is the structural element $(\mathrm{S})$ which is the novelty in comparison with the previous researches. The Cultural Element (C) or a system of values, norms, beliefs, customs that are internalized by individuals, communities, or members of the community to form a pattern of attitudes and behavior as part of the adopted culture has been derived from the special designation city with its Free Trade Zone and involved facilities. The Processual Elements (P) is the dynamics of informal and day-to-day interactions among community members who have not been formally structured or cultured, where expressions, discussions, negotiations of different aspirations occur dynamically, which is mainly the issue on the international port city and the maritime-related development, as well as its social dynamics. We can determine the quality of socio-cultural condition of the City of Batam based on the findings on social resilience and nationalism categories (Table 4).

Table 4. Matrix of Relationship between Structural-Processual-Cultural Elements for Social Resilience and Culture of Nationalism Category

\begin{tabular}{ccccccc}
\hline Category & $\begin{array}{c}\text { Structural } \\
\text { Element }\end{array}$ & $\begin{array}{c}\text { Structural- } \\
\text { Cultural } \\
\text { Element }\end{array}$ & $\begin{array}{c}\text { Cultural } \\
\text { Element }\end{array}$ & $\begin{array}{c}\text { Cultural- } \\
\text { Processual } \\
\text { Element }\end{array}$ & $\begin{array}{c}\text { Processual } \\
\text { Element }\end{array}$ & $\begin{array}{c}\text { Processual- } \\
\text { Structural } \\
\text { Element }\end{array}$ \\
\hline Transformation (R) & & $\star(\mathrm{SC})$ & $\star$ & $\star(\mathrm{PC})$ & $\star$ & \\
Adaptation (R) & $\diamond$ & $\boldsymbol{v}(\mathrm{SC})$ & $\diamond$ & $\boldsymbol{v}(\mathrm{CP})$ & & $\times(\mathrm{SP})$ \\
Adoption (R) & $\diamond$ & $\boldsymbol{v}(\mathrm{SC})$ & $\diamond$ & & $\checkmark$ & $\times(\mathrm{PS})$ \\
Security (N) & $\star$ & $\star(\mathrm{SC})$ & $\star$ & & $\star$ & \\
Justice (N) & $\diamond$ & & & & $\diamond$ & $\diamond(\mathrm{SP})$ \\
Environmental Governance (N) & $\star$ & $\star(\mathrm{CS})$ & $\boldsymbol{\times}$ & $\mathbf{\times}(\mathrm{CP})$ & $\star$ & \\
\hline
\end{tabular}




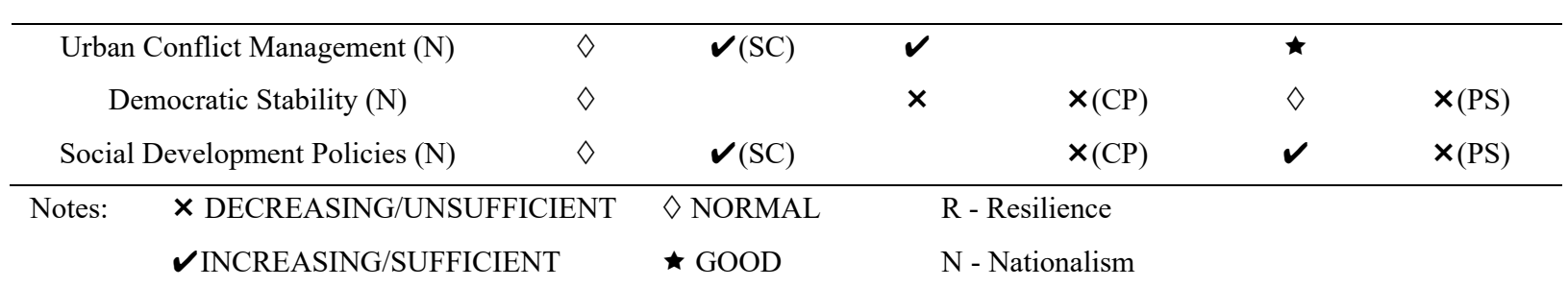

The structural element shows that security and environmental governance are within the "good" category. It means there are rules and regulations and they have been socially accepted and well implemented. However, these two categories are also the most progressive in the processual element. The dynamics are high, and it is mainly due to the City's strive to make a high standard international port city that also subjects to international regulations on environmental standards including safety and security. The high dynamics society also leads to continuous transformation has become a structured culture (SC), and where the good lesson learned becomes a processed culture (PC). The peace culture is flourishing since tolerance, multiculturalism, safety, and security are considered essential matters and have become the local identity that should be preserved and maintained. Being a part of a global citizen is a realization that has been well accepted by the residents, especially with their interactions with many foreigners who come to the City for business and pleasure. In this case, environmental governance and security fall in the structured culture (SC) criteria.

The need of having a livable city that provides more quality of living has been increasingly urgent. The residents of Batam through many social engagements urge the government to make this value into a more binding one. In this case, the cultured structure (CS) can be seen in environmental governance. The transformation category is also within the "the good" category in structured culture (SC) and processed culture (PC) criteria. We can say that the spirit to make progress to a better social resilience is always on the go, and the transformation has become the culture $(\mathrm{C})$ of the society even though it might not be supported by swift responses of government in the term of adaptation and adoption that reflected in agile decision making. The development process in the City of Batam that strive to make the city into one of the showcases of Indonesian development makes the city continuously in its processual element (P), and it is where the culture of nationalism will continue to flourish as the people want to realize the City of Batam to stand equally with other modern cities.

Conversely, we should pay more attention to democratic stability. The local politics is the primary concern since there are some issues in the government policies create some confusion on the strategic mission of the city. Most of the informants show their concern in the processed structure (PS) of many favorable rules, regulations and government policies that may not lead to the economic benefit that can bounce the city back to its previous progress as one of the highest increasing economic level city in Indonesia. Majority of informants was also questioning the swift responses to the downturn economics and the lack of adaptation (structured processual tendency) and adoption (processed structural tendency) to the rapid industrial movement in the available education and skills training to create ready-to-work workforces. However, free people movement lead to many illegal residents in the City of Batam give more burden to the social condition in the city, including more demands on vocational education and training that suit the job openings. Social development policy that can support the innovation in social development is considered insufficient in comparison to the needs of the residents, in which based on its processed structural (PS) nature is the source of residents' complaints.

The City of Batam has a good foundation as a created city from scratch to become an industrial city. In this case, the necessary infrastructures to provide clean water, sanitation management, waste treatments management have been available along with the progress of the city. The infrastructures are not only created a substantial structural element for the city but also create the culture of the city. This condition is reflected in the analysis results in Table 5. Unfortunately, there is a tendency to disregarding the rules in the residential area or the further area from the city center. It is where the structure is being processed (SP) based on various reasons. The limited environment condition of the City of Batam in which the islands and islets are very receptive to climate change makes the limited natural resources such as water need to be continuously maintained to be able to fulfill the need of the future generation. In addition to that, being an international port city, maintaining the top physical environment condition is very crucial to the sustainability of the city and its livelihood. The main concern on the maritime aspects for sustainable development is the plastic waste in the coastal area and other kinds of pollution drifted by the currents from the international waters. The good structural element for coastal protection is processed (SP) due to some parties who take advantages of this situation by not giving proper environmental protection. 
Due to its prosperity, the City of Batam is still able to maintain its decent living standard. However, the shift in the industry should be given more attention. It is not only in the maritime-related industry aspect but also to other determinants in the support towards living and employment category. As an industrial city, loss of jobs will lead to more social problems related to safety and security. With the growing demography condition, this condition may lead to social unrest. With such condition, innovation in the economic situation is also a part of urban conflict management, and it involves and cannot be separated from investment, workforce, and development policies.

Table 5. The Matrix of Relationship between Structural-Processual-Cultural Elements for the Planet Section of the Sustainable Development Goals

\begin{tabular}{|c|c|c|c|c|c|c|}
\hline Category & $\begin{array}{l}\text { Structural } \\
\text { Element }\end{array}$ & $\begin{array}{l}\text { Structural- } \\
\text { Cultural }\end{array}$ & $\begin{array}{l}\text { Cultural } \\
\text { Element }\end{array}$ & $\begin{array}{l}\text { Cultural- } \\
\text { Processual }\end{array}$ & Processual & $\begin{array}{l}\text { Processual- } \\
\text { Structural }\end{array}$ \\
\hline Clean water $(\mathrm{E})$ & $\star$ & $\boldsymbol{\nu}(\mathrm{SC})$ & $\star$ & $\star(\mathrm{PC})$ & $\star$ & \\
\hline Sanitation (E) & $\star$ & & & & $\boldsymbol{\nu}$ & $\times(\mathrm{SP})$ \\
\hline Solid waste (E) & $\star$ & $\star(\mathrm{SC})$ & & $\star(\mathrm{PC})$ & & $\times(\mathrm{SP})$ \\
\hline Liquid Waste (E) & $\star$ & $\star(\mathrm{SC})$ & & $\star(\mathrm{PC})$ & & $\times(\mathrm{SP})$ \\
\hline Environmental Protection (E) & $\star$ & $\boldsymbol{V}(\mathrm{SC})$ & & & & $\times(\mathrm{SP})$ \\
\hline $\begin{array}{c}\text { Employment and employment } \\
\text { opportunity (S) }\end{array}$ & & & & & $\diamond$ & $\diamond(\mathrm{SP})$ \\
\hline Access to make a decent living (S) & & $\star(\mathrm{SC})$ & $\star$ & & $\star$ & $\boldsymbol{V}(\mathrm{SP})$ \\
\hline Access to social welfare $(\mathrm{S})$ & & & $\star$ & & $\checkmark$ & \\
\hline Support toward innovation (S) & & & & & $\checkmark$ & \\
\hline $\begin{array}{c}\text { Maritime aspects for sustainable } \\
\text { development (S) }\end{array}$ & $\diamond$ & & & & $\boldsymbol{\nu}$ & $\times(\mathrm{SP})$ \\
\hline Investments (L) & $\diamond$ & & & & $\boldsymbol{V}$ & $\times(\mathrm{SP})$ \\
\hline Job training and skill training $(\mathrm{L})$ & & $\boldsymbol{\nu}(\mathrm{SC})$ & & & $\checkmark$ & \\
\hline Workforce policies (L) & $\diamond$ & & & & $\diamond$ & $\times(\mathrm{SP})$ \\
\hline Development policies (L) & $\diamond$ & & & & $\diamond$ & $\times(\mathrm{SP})$ \\
\hline \multicolumn{2}{|c|}{ × DECREASING/UNSUFFICIENT } & \multicolumn{5}{|c|}{ E - Environmental Protection and Degradation } \\
\hline \multicolumn{2}{|l|}{$\diamond$ NORMAL } & \multicolumn{5}{|c|}{ S - Sustainable Consumption and Production } \\
\hline \multicolumn{2}{|c|}{$\boldsymbol{\sim}$ INCREASING/SUFFICIENT } & \multicolumn{5}{|c|}{$\mathrm{L}$ - Support for Living and Employment } \\
\hline$\star \mathrm{GOOD}$ & & & & & & \\
\hline
\end{tabular}

Locally, the grand idea in the City of Batam's vision is to build a port city with an advanced society in terms of thinking, spirituality, and material wealth. Nationalism is interpreted related to the maritime culture and prosperity generated from the maritime industry. Therefore, it is not secluded, but it always seeks interaction among nations, in this case, foreign investments, in order to create prosperity that can be of benefits to the entire nation. According to the meta-analysis, community transformation with sufficient efforts supported by good governance is the most applicable in building social resilience and the culture of nationalism. Based on the analysis of the structural-processual-cultural elements, both industrial culture and island living has been immersed in the community despite the original hometown of the residents. However, the community still waits for guidance to do the transformation and social changes in order to achieve prosperity generated by the maritime industry from the government and other influential stakeholders. Despite the economic downturn, the community still strives to do their best for their islands and Indonesia in general. Based on this fact, we can state that the level of nationalism can be considered as very good.

In the national level, nationalism is often discussed more on aspects of love for the country, patriotism, and being loyal to the country. However, for City of Batam communities, nationalism does not have any correlation with staying in the country or being secluded locally. Located in the state border area, with Singapore and Malaysia as 
neighbors, the geographical distance to other countries is shorter than to the central government of Indonesia. Despite the better economic condition that offered overseas, City of Batam still has its attachment and people willing to serve for better development of their city. In this case, social resilience can be seen as striving efforts to match up with Singapore (85\% of the respondents) or match up with Johor, Malaysia $(62 \%$ of the respondents). The most discussed issues in order to increase community resilience are security and justice, environmental governance for island development, and democratic stability with clear guidance of development policies from the central government. We should see that for the regional level and beyond, the efforts to match up with Singapore with various development ways shows a culture of regional nationalism. In this case, the City of Batam's residents try their best collectively sharing their will to strive for the best and stands equally among other nations.

\section{Conclusion}

We conclude that increased social resilience has impacts on the determinants of building a culture of nationalism. Increased social resilience is due to social transformation and efforts to make a better transformation, social resilience adoption and adaption, as well as social capacity building through many aspects of development efforts as well as interaction with many nations.

Development in economic aspects and political powers cannot be separated in the discussion of building a culture of nationalism since an increased culture of nationalism also creates feedback to increased social resilience and giving more spirit to create better social resilience. A sense of nationalism is also a part of building society's social resilience as well, and nationalism is not correlated with the place of living but to the efforts of citizen participation in sustainable development. Therefore, the development may lead to creating sustainable social resilience, and by creating collective participation and knowledge in developing social resilience, the residents are also participating in building a culture that is able to activate social justice along with other citizens of Indonesia, or building a culture of nationalism as intended for nation building as mentioned by Indonesia's Founding Father.

However, further research is needed on the in-depth insight of changing development that affects determinants of social and economic development locally, nationally, and regionally. Since these dynamics are highly interconnected with political nuance, social resilience may show other transformation and adaptation in how people perceive the culture of nationalism and sustainable development.

\section{Conflict of interest}

No potential conflict of interest was reported by the authors.

\section{Acknowledgments}

The authors are wishing to acknowledge encouragement from School of Environmental Science, Universitas Indonesia and thank the reviewers for their helpful inputs. This work was supported by Universitas Indonesia Grant No. 6626/UN2.R3.1/PPM.00.01/2018.

\section{References}

Adger, W. N. (2000, September). Social and ecological resilience: Are they related? Progress in Human Geography, 24(3), 347-364. https://doi.org/10.1191/030913200701540465

Badan Pengusahaan Batam. (2014). Mengungkap Fakta Pembangunan Batam Era B.J. Habibie. (Revealing Batam's Development Facts in B.J. Habibie's Era) Batam: Badan Pengusahaan Batam.

Beel, D. E., Wallace, C. D., Webster, G., Nguyen, H., Tait, E., Macleod, M., \& Mellish, C. (2017, August). Cultural resilience: The production of rural community heritage, digital archives and the role of volunteers. Journal of Rural Studies, 54, 459-468. https://doi.org/10.1016/j.jrurstud.2015.05.002

Bloom, W. (1990). Personal identity, national identity, and international relations. Cambridge: Cambridge University Press.

Bridge, G. (2018). The map is not the territory: A sympathetic critique of energy research's spatial turn. Energy Research \& Social Science, 36, 11-20. https://doi.org/10.1016/j.erss.2017.09.033

Bošković, A. (2002). Clifford Geertz: Writing and Interpretation. Sociologija, XLIV(1), 41-56.

Castanho, R., Loures, L., Fernández, J., \& Pozo, L. (2018, February). Identifying critical factors for success in Cross Border Cooperation (CBC) development projects. Regional Intelligence: A new kind of GIScience, 72, 92-99. https://doi.10.3390/su9030360

Community and Regional Resilience Institute. (2013). Definitions of Community Resilience: An Analysis. A 
CARRI Report. Washington, DC: CARRI and Meridian Institute.

Connon, I. L. (2017). Extreme weather, complex spaces and diverse rural places: An intra-community scale analysis of responses to storm events in rural Scotland, UK. Journal of Rural Studies, 54, 111-125. https://doi.org/10.1016/j.jrurstud.2017.06.015

Delina, L. L. (2018). Energy democracy in a continuum: Remaking public engagement on energy transition in Thailand. Energy Research \& Social Science, 42, 53-60. https://doi.org/10.1016/j.erss.2018.03.008

Dreze, J., \& Sen, A. (1999). India: Economic Development and Social Opportunity. Oxford: OUP Catalogue, Oxford University Press.

Drucza, K., \& Peveri, V. (2018). Review: Literature on gendered agriculture in Pakistan: Neglect of women's $\begin{array}{lllll}\text { contributions. Women's } \quad \text { Studies International Forum, } & \text { 69, }\end{array}$ https://doi.org/10.1016/j.wsif.2018.02.007

Dukpa, R. D., Joshi, D., \& Boelens, R. (2018). Hydropower development and the meaning of place. Multi-ethnic $\begin{array}{lllll}\text { hydropower struggles in Sikkim, India. Geoforum, } & 89,\end{array}$ https://doi.org/10.1016/j.geoforum.2018.01.006

Fröhlich, C., \& Gioli, G. (2015). Gender, Conflict, and Global Environmental Change. Peace Review: A Journal of Social Justice, 27(2), 137-146. https://doi.org/10.1080/10402659.2015.1037609

Ganbold, M., \& Ali, S. H. (2017, September). The peril and promise of resource nationalism: A case analysis of Mongolia's mining development. Resources Policy, 53, 1-11. https://doi.org/10.1016/j.resourpol.2017.05.006

Guarnacci, U. (2016, June). Joining the dots: Social networks and community resilience in post-conflict, post-disaster Indonesia. International Journal of Disaster Risk Reduction, 16, 180-191. https://doi.org/10.1016/j.ijdrr.2016.03.001

Hansen, A. M., Vanclay, F., Croal, P., \& Skjervedal, A. S. H. (2016). Managing the social impacts of the rapidly-expanding extractive industries in Greenland. The Extractive Industries and Society, 3(1), 25-33. https://doi.org/10.1016/j.exis.2015.11.013

Heinderyckx, F. (2015). Transnational News Media and the Elusive European Public Sphere. International Journal of Communication, 9, 3161-3176.

Hirsch, E. (2015). "It won't be any good to have democracy if we don't have a country": Climate change and the politics of synecdoche in the Maldives. Global Environmental Change, 35, 190-198.

Hoang, Lan Anh, L. A., Lam, T., Yeoh, B. S., \& Graham, E. (2015, June). Transnational migration, changing care arrangements and left-behind children's responses in South-East Asia. Children's Geographies, 13(3), 263-277. https://doi.org/10.1080/14733285.2015.972653

Hoffmann, C. (2018, July). Beyond the resource curse and pipeline conspiracies: Energy as a social relation in the Middle East. Energy Research \& Social Science, 41, 39-47. https://doi.org/10.1016/j.erss.2018.04.025

Høyland, S. A. (2018). Exploring and modelling the societal safety and societal security concepts - A systematic review, empirical study and key implications. Special Issue on societal safety, critical infrastructure reliability and related intersectoral governance. Safety Science (110 Part C), 7-22.

Jati, W. R. (2017). Relasi Nasionalisme dan Globalisasi Kontemporer: Sebuah Kajian Konseptual (Relation of Nationalism and Contemporary Globalism: A Conceptual Study). Yogyakarta: LIPI \& Pustaka Pelajar.

Kellas, J. G. (1998). The Politics of Nationalism and Ethnicity. London: Palgrave Macmillan.

Kluvánková, T., Brnkaláková, S., Špaček, M., Slee, B., Nijnik, M., Valero, D., \& Gežík, V. (2018, December). Understanding social innovation for the well-being of forest-dependent communities: A preliminary theoretical framework. Forest Policy and Economics, 97, 163-174. https://doi.org/10.1016/j.forpol.2018.09.016

Miller, J. L., \& Pescaroli, G. (2018). Psychosocial capacity building in response to cascading disasters: A culturally informed approach. International Journal of Disaster Risk Reduction, 30(Part B), 164-171. https://doi.org/10.1016/j.ijdrr.2018.04.018

Mylonas, H., \& Kuo, K. (2018). Nationalism and Foreign Policy. In C. G. Thies, \& C. G. Thies (Eds.), The Oxford Encyclopaedia of Foreign Policy Analysis (pp. 594-595). Oxford: Oxford University Press. https://doi.org/10.1093/acrefore/9780190228637.013.452 
Noboa, E., \& Upham, P. (2018). Energy policy and transdisciplinary transition management arenas in illiberal democracies: A conceptual framework. Energy Research \& Social Science, 46, 114-124. https://doi.org/10.1016/j.erss.2018.07.014

Shah, P. P. (2016). Partnerships and appropriation: translating discourses of access and empowerment in girls' education in India. International Journal of Educational Development, 49, 11-21. https://doi.org/10.1016/j.ijedudev.2016.02.001

Shah, R., \& Lopes Cardozo, M. (2014). Education and social change in post-conflict and post-disaster Aceh, $\begin{array}{lllll}\text { Indonesia. International Journal of Educational Development, } 38, & 2-12 .\end{array}$ https://doi.org/10.1016/j.ijedudev.2014.06.005

Smith, A. D. (1991). National Identity. Nevada: University of Nevada Press.

Soekarno. (2006). Filsafat Pancasila Menurut Bung Karno (Pancasila Philosophy According to Bung Karno). Yogyakarta: Media Pressindo.

Stenbacka, S., \& Bygdell, C. (2018). The cosmopolitan farmer: Ideas and practices beyond travel and internationalisation. Journal of Rural Studies, 61, 63-72. https://doi.org/10.1016/j.jrurstud.2018.06.001

Tsai, I.-T. (2018, July). Political economy of energy policy reforms in the gulf cooperation council: Implications of paradigm change in the rentier social contract. Energy Research \& Social Science, 41, 89-96. https://doi.org/10.1016/j.erss.2018.04.028

United Nations. (2015). Transforming Our World: The 2030 Agenda for Sustainable Development. Retrieved from https://sustainabledevelopment.un.org/content/documents/21252030\%20Agenda $\% 20$ for $\% 20$ Sustainab le\%20Development $\% 20$ web.pdf

von Heland, J., \& Folke, C. (2014, January). A social contract with the ancestors-Culture and ecosystem services in southern Madagascar. Global Environmental Change, 24, 251-264. https://doi.org/10.1016/j.gloenvcha.2013.11.003

Walters, P. (2015, December). The problem of community resilience in two flooded cities: Dhaka 1998 and Brisbane 2011. Habitat International, 50, 51-56. https://doi.org/10.1016/j.habitatint.2015.08.004

Wilmsen, B., \& Webber, M. (2015). What can we learn from the practice of development-forced displacement and resettlement for organised resettlements in response to climate change? Geoforum, 58, 76-85. https://doi.org/10.1016/j.geoforum.2014.10.016

Wirutomo, P. (2014). Sociological Reconceptualization of Social Development: with Empirical Evidence from Surakarta City, Indonesia. Asian Social Science, 10(11), 283-293. https://doi.org/10.5539/ass.v10n11p283

Wirutomo, P. (2016). Dealing with Brawls in Jakarta's Slum Area: Pursuing Social Development through Social Engagement. The Senshu Social Well-Being Review, 93-109

Zimmerer, K. S. (2015, August). Environmental governance through "Speaking Like an Indigenous State" and respatializing resources: Ethical livelihood concepts in Bolivia as versatility or verisimilitude? Geoforum, 64, 314-324. https://doi.org/10.1016/j.geoforum.2013.07.004

\section{Copyrights}

Copyright for this article is retained by the author(s), with first publication rights granted to the journal.

This is an open-access article distributed under the terms and conditions of the Creative Commons Attribution license (http://creativecommons.org/licenses/by/4.0/). 